\title{
Ketosis-onset diabetes in Tunisian adults: immunological markers and $\beta$-cell function
}

\author{
F. Harzallah, ${ }^{1}$ A. Ben Brahim, ${ }^{1}$ L. Laadhar, ${ }^{2}$ M.Feki, ${ }^{3}$ M. Zitouni, ${ }^{2}$ S. Makni, ${ }^{2}$ N. Kaabachi ${ }^{3}$ and H. Slimane
}

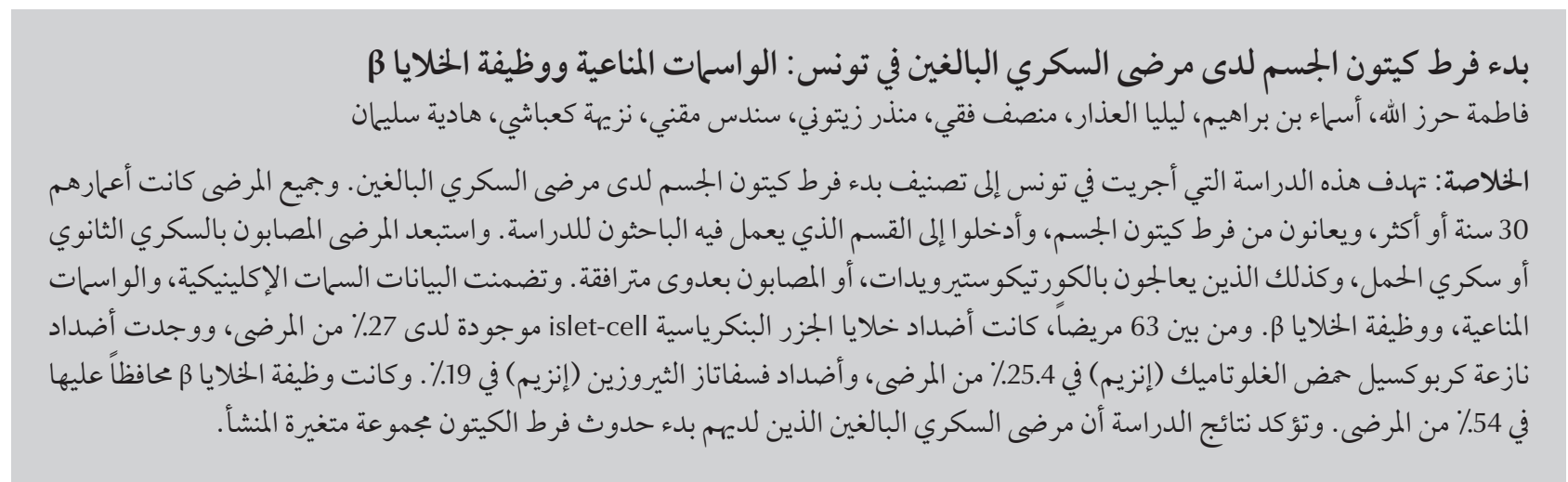

ABSTRACT The aim of this study in Tunisia was to classify ketosis-onset diabetes in adult patients. All patients aged $\geq 30$ years without known diabetes, presenting with ketosis and admitted to our department were studied. Patients with secondary or gestational diabetes and those on corticoid therapy or with coinciding infection were excluded. The data included clinical characteristics, immunological markers and $\beta$-cell function. Of the 63 patients, islet-cell antibodies were present in $27.0 \%$, glutamic acid decarboxylase antibodies in $25.4 \%$ and thyrosin phosphatase antibodies in $19.0 \%$. $\beta$-cell functional reserve was preserved in $54.0 \%$. Our results confirm that patients with ketosis-onset diabetes mellitus in adulthood are a heterogeneous group.

Diabète débutant par une cétose chez des adultes tunisiens : marqueurs immunologiques et fonction de la cellule $\beta$

RÉSUMÉ L'objectif de cette étude menée en Tunisie était de classifier le diabète débutant par une cétose chez des patients adultes. Tous les patients âgés de 30 ans ou plus sans diabète connu, présentant une cétose et admis dans notre service ont été étudiés. Nous avons exclu ceux atteints d'un diabète secondaire ou gestationnel et ceux sous corticothérapie ou présentant une co-infection. Les données comprenaient les caractéristiques cliniques, les marqueurs immunologiques et la fonction de la cellule $\beta$. Des anticorps anti-îlots de Langerhans étaient présents chez $27,0 \%$ des 63 patients, des anticorps anti-acide glutamique décarboxylase chez 25,4\% d'entre eux et des anticorps anti-thyrosine phosphatase chez 19,0\% d'entre eux. La masse fonctionnelle des cellules $\beta$ était préservée chez $54,0 \%$ des patients. Nos résultats confirment que les patients atteints d'un diabète sucré débutant par une cétose à l'âge adulte constituent un groupe hétérogène.

${ }^{7}$ Department of Endocrinology and Diabetology; ${ }^{2}$ Immunology Laboratory; ${ }^{3}$ Biochemistry Laboratory, La Rabta Hospital, Tunis, Tunisia (Correspondence to F. Harzallah:fatma.harzallah@rns.tn).

Received: 18/05/07; accepted: 27/09/07 


\section{Introduction}

Despite the difference in physiopathological mechanisms of type 1 and type 2 diabetes, the distinction between the 2 types can be notoriously difficult at the time of diagnosis, particularly in atypical presentations [1].

Ketosis-onset diabetes is the most common presentation of adult patients in our department [2] and it can lead to a problem of classification. Acute onset, particularly with ketosis, was previously considered to be a characteristic feature of type 1 diabetes [3]. However, descriptions of atypical presentations, characterized by a prolonged remission after acute need for insulin, demonstrate that type 2 diabetes may start with ketosis without any known precipitating factor [4]. Ethnic differences in initial presentation of type 2 diabetes are well documented and seem to be a consequence of a predominant insulin secretory defect in people of African ancestry and a potential difference in ketogenesis among ethnic groups $[5,6]$.

The Tunisian population has a growing epidemic of diabetes [7]. The aim of this study in Tunis, the capital city of Tunisia, was to classify newly diagnosed diabetes in adult patients who presented initially with ketosis.

\section{Methods}

We included in this case series study all adult patients aged $\geq 30$ years with newly diagnosed diabetes who presented with an acute-onset ketosis to the emergency department and were admitted to our department between July 2003 and July 2005. Ketosis onset was defined as the presence of hyperglycaemia (> $2 \mathrm{~g} / \mathrm{L})$, ketonuria and immediate need for insulin without previously known diabetes. Patients with secondary or gestational diabetes and those on corticoid therapy or with an infectious disease were excluded. A total of 63 consecutive, unrelated Tunisian patients were investigated.

Data were collected on clinical characteristics (family history of diabetes, associated diseases, age, symptoms and anthropometric features), biological parameters [glycaemia, total and highdensity lipoprotein (HDL)-cholesterol and triglycerides performed once at the time of the study in a fasting state], immunological markers and $\beta$-cell function.

Islet-cell antibodies (ICA) were detected by indirect immunofluorescence using monkey pancreas sections (The Binding Site, UK). Glutamic acid decarboxylase (GADA) and thyrosin phosphatase antibodies (IA-2A) were detected by radio-immunoprecipitation (Euroimmun, Germany). $\beta$-cell function was assessed at least 1 week after the acute episode, when patients were in a nearly normoglycaemic state. C-peptide levels were assessed at fasting state and 6 minutes after intravenous administration of $1 \mathrm{mg}$ glucagons by the radio-immunological method using a commercial kit (Immunotech, France). $\beta$-cell functional reserve was considered preserved if the fasting C-peptide level was $>1 \mathrm{ng} / \mathrm{dL}$ or glucagon-stimulated C-peptide $>1.5 \mathrm{ng} / \mathrm{dL}$.

Data were analysed using Epi-Info, version 6. Results are expressed as mean and standard deviation (SD). Analysis of variance or the Kruskall-Wallis tests were used to compare means and the chi-squared test to compare proportions. Pair-wise comparisons were made when there were significant differences between groups.

\section{Results}

A total of 63 patients ( 23 women) aged $\geq 30$ years presenting with ketosis were investigated. Among them, 36 (57.1\%) reported a family history of diabetes. All patients complained of polyuria and polydipsia, with a median duration of 30 days (range: 2 days to 1 year), and 80\% reported weight loss. Four patients had associated autoimmune disease. The mean age of our patients was 46.0 (SD 11.6) years and the mean body mass index (BMI) was $26.0($ SD 5.4$) \mathrm{kg} / \mathrm{m}^{2}$. BMI was $\geq 25 \mathrm{~kg} / \mathrm{m}^{2}$ in $52.4 \%$ of cases.

ICA were present in 17 (27.0\%), GADA were detected in 16 (25.4\%) and IA-2A were positive in $12(19.0 \%)$ of patients. At least 1 immunological marker was detected in 23 cases (36.5\%). The mean C-peptide level was $1.07(\mathrm{SD} 0.80) \mathrm{ng} / \mathrm{mL}$ at fasting and $1.42($ SD 1.07$) \mathrm{ng} / \mathrm{mL}$ after glucagon. $\beta$-cell functional reserve was preserved in $54.0 \%$ of patients.

According to immunological markers (present $A+$ or absent $A-$ ) and $\beta$-cell functional reserve (present $\beta+$ or absent $\beta-$ ), our patients were divided into 4 groups: 14 patients $(22.2 \%)$ were $\mathrm{A}+$ $\beta-; 15(23.8 \%)$ were $A-\beta-, 9(14.3 \%)$ were $A+\beta+$; and $25(39.7 \%)$ were $A-$ $\beta+$

Among the 14 patients who were $A+\beta-, 12(86 \%)$ were positive for GADA, 9 (64\%) for IA-2A and 6 (43\%) for both antibodies. In the group who were $A+\beta+$, positive antibodies were mainly ICA, detected in 7 (78\%) of the 9 patients.

There were no significant group differences in the sex ratio and in the proportions of patients with a family history of diabetes. Mean BMI and waist circumference increased significantly from group $A+\beta$ - to $A-\beta+(P<0.01)$ (Table 1).

The $A+\beta$ - group, i.e. patients with immunological markers and $\beta$-cell deficiency, was the youngest group, with the lowest means of BMI, waist circumference, total cholesterol and triglycerides. The HDL level was the highest in the A+ $\beta$-group (Tables 1 and 2 ).

The 2 groups with preserved $\beta$-cell function $(A+\beta+$ and $A-\beta+)$ were similar in most clinical features and biological parameters. 


\begin{tabular}{|c|c|c|c|c|c|}
\hline Characteristic & $\begin{array}{c}\text { Group } 1 \\
A+\beta- \\
(n=14)\end{array}$ & $\begin{array}{c}\text { Group } 2 \\
\text { A- } \beta- \\
(n=15)\end{array}$ & $\begin{array}{c}\text { Group } 3 \\
A+\beta+ \\
(n=9)\end{array}$ & $\begin{array}{c}\text { Group } 4 \\
\begin{array}{c}\text { A- } \beta^{+} \\
(n=25)\end{array}\end{array}$ & $P$-value \\
\hline Mean (SD) age (years) & $39(7)$ & $50(13)$ & $47(10)$ & $47(12)$ & $<0.07^{\mathrm{a}}$ \\
\hline Sex (no. of male:female) & $10: 4$ & $10: 5$ & $6: 3$ & 14:11 & NS \\
\hline Family history of diabetes (\%) & 64 & 60 & 67 & 48 & NS \\
\hline Associated autoimmune disease (no.) & 3 & 0 & 1 & 0 & NS \\
\hline Mean $(\mathrm{SD})$ waist circumference $(\mathrm{cm})$ & $80(10)$ & $90(12)$ & $93(12)$ & $100(12)$ & $<0.001^{c}$ \\
\hline Mean $(\mathrm{SD}) \mathrm{BMI}\left(\mathrm{kg} / \mathrm{m}^{2}\right)$ & $22.6(3.7)$ & $24.8(3.7)$ & $26.6(6.4)$ & $28.3(6.4)$ & $<0.01^{\mathrm{b}}$ \\
\hline Weight group (no.) & & & & & NS \\
\hline Lean $\left(<25 \mathrm{~kg} / \mathrm{m}^{2}\right)$ & 10 & 9 & 4 & 7 & \\
\hline Overweight $\left(<30 \mathrm{~kg} / \mathrm{m}^{2}\right)$ & 4 & 4 & 4 & 12 & \\
\hline Obese $\left(\geq 30 \mathrm{~kg} / \mathrm{m}^{2}\right)$ & 0 & 2 & 1 & 6 & \\
\hline
\end{tabular}

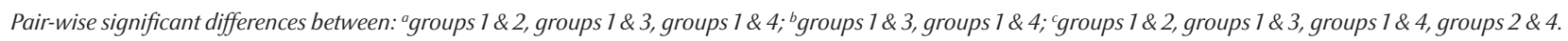
$S D=$ standard deviation; $B M I=$ body mass index; $N S=$ not significant .

\section{Discussion}

These results demonstrate that patients with ketosis-onset diabetesin adulthood are a heterogeneous group in which type 2 diabetes is the most frequent cause.

Despite the fact that we included all patients presenting with an acute onset ketonuria and not exclusively patients with acidosis, the proportion of typical type 1 diabetes with immunological markers and low $\beta$-cell functional reserve was relatively high $(22.2 \%)$, slightly more than reported by Maldonado (17\%) in a multi-ethnic study with younger patients [8]. It may suggest that autoimmune type 1 diabetes contributes to the increasing incidence of diabetes in the Tunisian adult population.

Ketosis-prone diabetes with remission is a well-known sub-type of type 2 diabetes rather than type 1 . The acute presentation at diagnosis or sometimes later is explained by a functional and partially reversible $\beta$-cell deficiency $[8,9]$. This subtype was the most frequent in our study (39.7\%) and to our knowledge this is the first time that such presentation has been documented in a North African population. Ketosisprone type 2 diabetes, first reported in black populations $[10,11]$, is distinguishable from other subtypes by clinical and biological features of the metabolic syndrome [12]. Indeed, mean BMI, waist circumference and triglycerides were the highest in this group in our study. However, the mean BMI as well as the triglycerides were lower in our patients than levels reported in other studies $[13,14]$, probably because of a lower rate of insulin resistance in our population. Moreover, the presence of the metabolic syndrome is more frequently associated with preserved $\beta$-cell function, and consequently a better glycaemic control after the acute episode and long-term remission $[14,15]$. In this kind of type 2 diabetes, the acute $\beta$-cell failure inducing ketosis $[15]$ seems to be linked to a genetic propensity to glucotoxicity and lipotoxicity $[16-18]$.

Diabetes in patients with $\beta$-cell deficiency and without immunological markers may belong to type $1 \mathrm{~A}$, since it is well demonstrated that auto-antibodies may be absent even when the initial process of diabetes is an autoimmune reaction [19]. Our patients in this group were the oldest and leanest and 2 scenarios may be possible: the disappearance of autoantibodies with evolution of type 1 diabetes or a decline in $\beta$-cell function some years after the hyperglycaemic state that initiated authentic type 2 diabetes [20]. The presence of diabetes-associated autoantibodies confirm the process leading to $\beta$-cell alteration and, as expected, they were detected in our 4 patients with associated autoimmune disease. In type $1 A$ diabetes, the frequencies of ICA and IA2 positivity decreased with increasing age, whereas the frequency of GADA positivity increased [21]. The absence of all 3 tested immunological markers and the clinical features, mainly age and $\mathrm{BMI}$, in our $\mathrm{A}-\beta$-group argue in favour of the latter hypothesis. However, the possibility of idiopathic type 1 diabetes cannot be excluded. This type, classified as $1 \mathrm{~B}$, is frequent in Japanese adults [22] and reported to be around $12 \%$ among young typical type 1 Italian patients [21]. The relationship between $\beta$-cell function and autoantibodies varies between studies, but the presence of immunological markers is mostly associated with greater decline in insulin secretion $[21,23]$. The patients with ketosis-prone type 2 diabetes and permanentinsulindependencerepresented about $25 \%$ in a cohort of patients of subSaharan African origin [16]. They were different from type 1 diabetic patients 


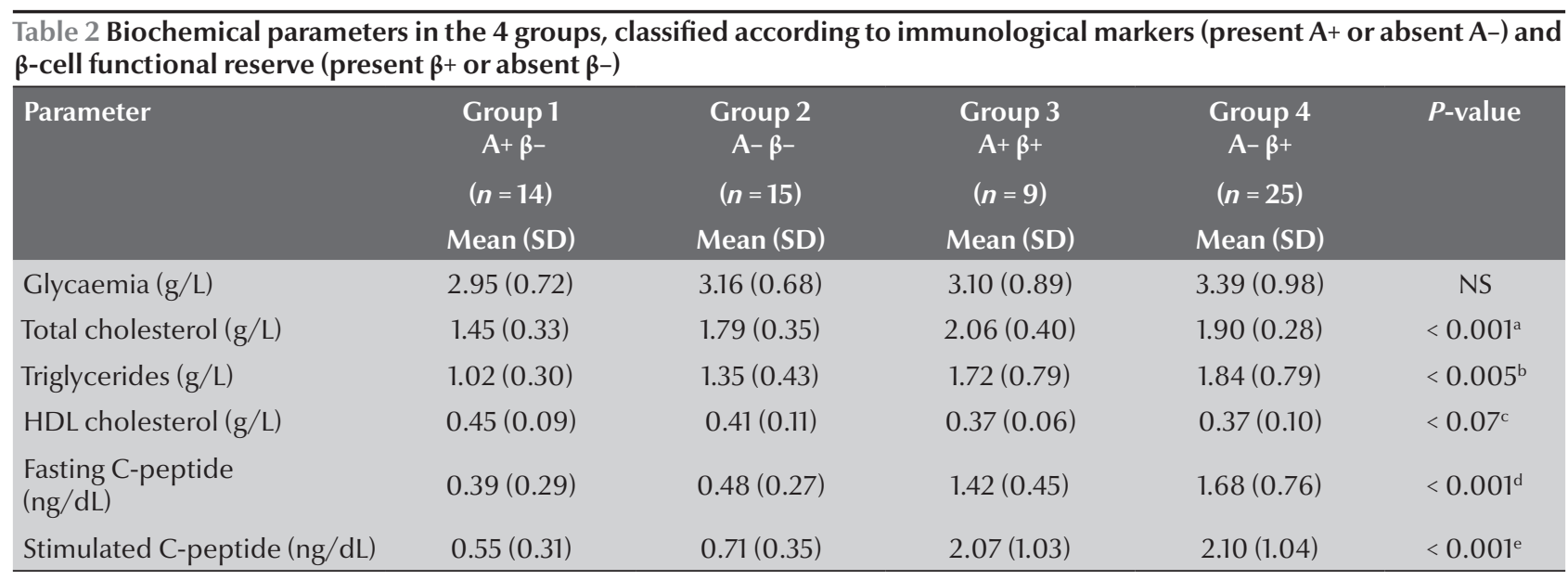

Pair-wise significant differences between: ${ }^{a}$ groups 1 \& 2, groups 1 \& 3, groups 1 \& 4; ${ }^{b}$ groups 1 \& 2, groups 1 \& 3, groups 1 \& 4; groups 1 \& 3, groups 1 \& 4; ${ }^{d}$ groups 1 \& 3, groups $1 \& 4$, groups $2 \& 3$, groups $2 \& 4 ;$ e groups $1 \& 3$, groups $1 \& 4$, groups $2 \& 3$, groups $2 \& 4$. $S D=$ standard deviation; $N S=$ not significant; $H D L=$ high-density lipoprotein.

mainly because of maintenance of residual $\beta$-cell function some years after the diagnosis. In our study, C-peptide levels in this group (A- $\beta$ - group) were similar to autoimmune type 1 diabetic patients $(A+\beta-$ group $)$.

The most difficult patients to classify are those represented by the A+ $\beta+$ group with immunological markers and preserved $\beta$-cell function. These features may lead to the diagnosis of latent autoimmune diabetes in adults (LADA), which is defined as adultonset diabetes with circulating islet antibodies but not requiring insulin therapy initially [24]. It may not seem appropriate to consider this condition-revealed by an acute onset and temporary need for insulin — as latent diabetes. However, this kind of diabetes is characterized by features of type 2 diabetes and the autoimmune markers and so transient insulinopenia may occur as in ketosis-prone type 2 diabetes, leading to an acute onset and then followed by remission until progression to insulin dependence. The acute $\beta$-cell dysfunction is probably linked to an autoimmune process, which induces initially only functional alteration, without massive destruction of islet cells, as observed in type 1 diabetes [25]. Ketonuria was present at the moment of the diagnosis in about $30 \%$ of patients with slow type 1 diabetes in a French study [26].
In summary, the classification of diabetes using insulin secretion evaluation and immunological markers, which seems to be the most effective scheme [27], allowed us to distinguish 4 subgroups of patients. In more than half of the cases (autoimmune type 1 and ketosis-prone type 2 diabetes), patients may be diagnosed by classical characteristics. However, the 2 other subgroups may require further investigations, such as repeat testing of $\beta$-cell cell function or genetic studies.

In conclusion, ketosis-onset diabetes is in the majority of Tunisian adults a presentation of type 2 diabetes. However, autoimmune type 1 was more frequent than expected in this population.

\section{References}

1. Sobngwi E, Gautier JF. Adult-onset type I or ketosis-prone type II diabetes: evidence to revisit diabetes classification. Diabetologia, 2002, 45:283-5.

2. Harzallah F et al. Clinical and metabolic characteristics of newly diagnosed diabetes patients: experience of a university hospital in Tunis. Diabetes \& metabolism, 2006, 32:632-5.

3. Alberti KG, Zimmet PZ. Definition, diagnosis and classification of diabetes mellitus and its complications. Part 1: diagnosis and classification of diabetes mellitus provisional report of a WHO consultation. Diabetic medicine, 1998, 15:539-53.

4. Aizawa T et al. Ketosis-onset diabetes in young adults with subsequent non-insulin-dependency, a link between IDDM and NIDDM. Diabetic medicine, 1997, 14:989-91.

5. UK Prospective Diabetes Study. XII: Differences between Asian, Afro-Caribbean and white Caucasian type 2 diabetic patients at diagnosis of diabetes. Diabetic medicine, 1994, 11:670-7.

6. Kazlauskaite $\mathrm{R}$ et al. Ethnic differences predicting ketonuria in patients with type 2 diabetes. Journal of diabetes and its complications, 2005, 19:284-90.

7. Bouguerra R et al. The global diabetes pandemic: the Tunisian experience. European journal of clinical nutrition, 2007, 61:160-5.

8. Maldonado $\mathrm{M}$ et al. Ketosis-prone diabetes: dissection of a heterogeneous syndrome using an immunogenetic and betacell functional classification, prospective analysis, and clinical outcomes. Journal of clinical endocrinology and metabolism, 2003, 88:5090-8. 
9. Sobngwi E et al. Diabetes in Africans. Part 2: Ketosis-prone atypical diabetes mellitus. Diabetes \& metabolism, 2002, 28:5-12.

10. Winter WE et al. Maturity-onset diabetes of youth in black Americans. New England journal of medicine, 1987, 316:285-91.

11. Umpierrez GE et al. Diabetic ketoacidosis in obese AfricanAmericans Diabetes, 1995, 44:790-5.

12. Otiniano ME, Balasubramanyam A, Maldonado M. Presence of the metabolic syndrome distinguishes patients with ketosisprone diabetes who have a type 2 diabetic phenotype. Journal of diabetes and its complications, 2005, 19:313-8.

13. Umpierrez GE et al. Immunogenetic analysis suggests different pathogenesis for obese and lean African-Americans with diabetic ketoacidosis. Diabetes care, 1999, 22:1517-23.

14. Sobngwi E et al. Metabolic and immunogenetic prediction of long-term insulin remission in African patients with atypical diabetes. Diabetic medicine, 2002, 19:832-5.

15. Linfoot $\mathrm{P}$, Bergstrom C, Ipp E. Pathophysiology of ketoacidosis in type 2 diabetes mellitus. Diabetic medicine, 2005, 22:1414-9.

16. Mauvais-Jarvis F et al. Ketosis-prone type 2 diabetes in patients of sub-Saharan African origin: clinical pathophysiology and natural history of $\beta$-cell dysfunction and insulin resistance. Diabetes, 2004, 53:645-53.

17. Mauvais-Jarvis F et al. PAX4 gene variations predispose to ketosis-prone diabetes. Human molecular genetics, 2004, 13:3151-9.

18. Sobngwi E et al. High prevalence of glucose-6-phosphate dehydrogenase deficiency without gene mutation suggests a novel genetic mechanism predisposing to ketosis-prone diabetes. Journal of clinical endocrinology and metabolism, 2005, 90:4446-51.
19. Borg $\mathrm{H}$ et al. A 12-year prospective study of the relationship between islet antibodies and beta-cell function at and after the diagnosis in patients with adult-onset diabetes. Diabetes, 2002, 51:1754-62.

20. Goetz FC et al. Declining beta-cell function in type 2 diabetes: 5-year follow-up and immunologic studies of the population of Wadena, MN. Metabolism, 2002, 51:144-8.

21. Bruno $\mathrm{G}$ et al. Residual beta-cell function and male/female ratio are higher in incident young adults than in children: the registry of type 1 diabetes of the province of Turin, Italy, 1984-2000. Diabetes care, 2005, 28:312-7.

22. Imagawa A et al. A novel subtype of type 1 diabetes mellitus characterized by a rapid onset and an absence of diabetesrelated antibodies. Osaka IDDM Study Group. New England journal of medicine, 2000, 342:301-7.

23. Bakhtadze $\mathrm{E}$ et al. HLA-DQB1 genotypes, islet antibodies and beta cell function in the classification of recent-onset diabetes among young adults in the nationwide Diabetes Incidence Study in Sweden. Diabetologia, 2006, 49:1785-94.

24. Tuomi $\mathrm{T}$ et al. Clinical and genetic characteristics of type 2 diabetes with and without GAD antibodies. Diabetes, 1999, 48:150-7.

25. Shimada A et al. T-cell insulitis found in anti-GAD65+ diabetes with residual beta-cell function. A case report. Diabetes care, 1999, 22:615-7.

26. Dessalloud R et al. Autoimmune markers in slow type 1 diabetes: confrontation to type 1 diabetes. Diabetes and metabolism, 2000, 26:353-60.

27. Balasubramanyam A et al. Accuracy and predictive value of classification schemes for ketosis-prone diabetes. Diabetes care, 2006, 29:2575-9.

\section{Note from the Editor}

We wish to draw the kind attention of our potential authors to the importance of applying the editorial requirements of EMHJ when preparing their manuscripts for submission for publication. These provisions can be seen in the Guidelines for Authors, which are available online at http:/ / www.emro.who.int/emhj.htm, and are published at the end of the first issue of each volume. We regret that we are unable to consider papers that do not conform to the Guidelines. 